\title{
Sistem Pendukung Keputusan Penilaian Kelayakan Kredit dengan Menggunakan Metode Simple Additive Weighting di Koperasi Roda Sejahtera Semarang
}

\author{
Agung Riyantomo, Nugroho Eko Budiyanto, Aish Laksitasari \\ Jurusan Teknik Informatika, Fakultas Teknik, Universitas Wahid Hasyim \\ Jl. Menoreh Tengah X/22, Sampangan, Semarang 50236
}

\begin{abstract}
Abstrak
Penilaian kelayakan kredit yang dilakukan Koperasi Roda Sejahtera masih menggunakan cara manual, sehingga membutuhkan waktu yang lama untuk mengetahui nilai kelayakan kredit anggota yang baru diperoleh, untuk meningkatkan pelayanan dalam pemberian kredit di Koperasi Roda Sejahtera dibuatlah sistem pendukung keputusan penilaian kelayakan kredit dengan menggunakan Metode Simple Additive Weighting. Sistem penilaian menggunakan Kriteria 5C yaitu Character, Capacity, Capital, Collateral, Condition of Economy sistem pendukung keputusan ini menghasilkan penilaian kelayakan kredit lebih tepat dan akurat sehingga dapat meninimalkan adanya resiko kredit macet ataupun permasalah lain yang dapat merugikan Koperasi Roda Sejahtera Semarang.
\end{abstract}

Kata Kunci : Kredit, Simple Additive Weighting, Sistem Pendukung Keputusan.

\section{PENDAHULUAN}

\subsection{Latar Belakang}

Koperasi Simpan Pinjam adalah salah satu jenis koperasi yang ada di Indonesia yang mempunyai kegiatan utama adalah menyediakan jasa penyimpanan dan pinjaman dana kepada anggota koperasi dengan tujuan memajukan kesejahteraan anggota pada khususnya dan masyarakat pada umumnya.

Koperasi Roda Sejahtera Semarang harus hati-hati dalam menyalurkan kreditnya sebelum menyalurkan kredit kepada seorang calon nasabah. Koperasi Roda Sejahtera harus menilai terlebih dahulu kelayakan terhadap nasabah dalam pemberian kreditnya. Menilai suatu kelayakan terhadap nasabah dalam pemberian kredit bukanlah hal yang mudah karena melibatkan banyak faktor yang harus dipertimbangkan dan dianalisis dengan tepat, cermat, dan cepat. Hal ini mengingat keamanan dari kredit itu sendiri agar dikemudian hari tidak menimbulkan masalah yang menyulitkan pihak nasabah maupun merugikan pihak koperasi akibat pengembalian kredit yang kurang lancar bahkan macet.

Penilaian kelayakan kredit yang dilakukan Koperasi Roda Sejahtera saat ini masih menggunakan cara manual, sehingga membutuhkan waktu yang lama untuk mengetahui nilai kelayakan kredit anggota yang baru diperoleh. Sehingga dapat menimbulkan kesalahan dan ketidak telitian, kurangnya pengawasan terhadap kelengkapan data anggota yang mengajukan kredit dan banyaknya berkas-berkas yang harus dianalisa.

Dengan teknologi komputer yang hadir saat ini dengan berbagai kemampuan adalah jawaban atas permasalahan yang sedang dihadapi. Penggunaan sistem komputer ini diharapkan dapat menyelesaikan pekerjaan lebih baik dan lebih cepat.

\section{LANDASAN TEORI}

\subsection{Sistem Pendukung Keputusan}

Sistem Pendukung Keputusan (Decision Support System / DSS) merupakan sistem berbasis komputer yang diharapkan dapat membantu menyelesaikan masalah-masalah yang komplek dan tidak terstruktur maupun yang semi terstruktur. Sistem penunjan keputusan merupakan perpaduan antara manusia dan komputer Listiyono dkk, 2011). Konsep Sistem Pendukung Keputusan pertama kali diungkapkan pada tahun 1970 oleh Michael S.Cott Morton dengan istilah Management Decision System (Arfiyanti dan Purwanto, 2012).

\subsection{Pengertian Kredit}

Definisi kredit menurut Undang-Undang No. 14 tahun 1967 tentang pokok-pokok perbankan yang dimaksud dengan kredit adalah penyediaan uang atau tagihan-tagihan yang dapat disamakan dengan itu berdasarkan persetujuan pinjam meminjam antara bank dengan pihak lain dalam hal mana pihak peminjam berkewajiban melunasi utangnya 
setelah jangka waktu tertentu dengan jumlah bunga yang telah ditetapkan.

\subsection{Pengertian Simple Additive Weighting}

Metode Simple Additive Weighting merupakan metode penjumlahan terbobot. Konsep dasar metode SAW adalah mencari penjumlahan terbobot dari rating kinerja pada setiap alternatif pada semua atribut. Metode SAW membutuhkan proses normalisasi matriks keputusan (X) ke suatu skala yang dapat diperbandingkan dengan semua rating alternatif yang ada (Kusumadewi dkk, 2006)

$R i j=\left\{\begin{array}{l}\frac{X i j}{M a x X i j} \text { Jikaj adalah atribut keuntungan (benefit) } \\ \frac{M i n X i j}{X i j} \text { jikaj adalah atribut biaya (cost) }\end{array}\right.$

Gambar 2.1 Formula untuk mencari normalisasi

Dimana:

$r_{i j} \quad$ : Rating kinerja ternormalisasi

Max : Nilai maksimum dari setiap baris dan kolom

Min : Nilai minimum dari setiap baris dan kolom

Xij : Baris dan kolom dari matriks

benefit : Jika nilai terbesar adalah terbaik

cost : Jika nilai terkecil adalah terbaik

rij adalah rating kinerja ternormalisasi dari alternatif Ai pada atribut $\mathrm{Cj} ; \mathrm{i}=1,2, \ldots, \mathrm{m}$ dan $\mathrm{j}=1,2, \ldots, \mathrm{n}$.

\subsection{DBMS (Database Management System)}

DBMS merupakan suatu sistem perangkat lunak yang memungkinkan user (pengguna) untuk membuat, memelihara, mengontrol, dan mengakses database secara praktis dan efisien. Dengan DBMS, user akan lebih mudah mengontrol dan memanipulasi data yang ada (Solichin, 2009).

\subsection{PHP (Hypertext Preprocessor)}

PHP merupakan singkatan dari "Hypertext Preprocessor", pertama kali diperkenalkan oleh Rasmus Lerdorf pada tahun 1994. PHP memenuhi kebutuhan akan bahasa scripting server side yang sederhana, kuat, dan memiliki konektifitas dengan beragam database server (Dewi, 2011). Sebagian besar sintaks dalam PHP mirip dengan bahasa C, Java dan Perl, namun pada PHP ada beberapa fungsi yang lebih spesifik. Sedangkan tujuan utama dari penggunaan bahasa ini adalah untuk memungkinkan perancang web yang dinamis dan dapat bekerja secara otomatis.

\subsection{MySQL}

MySQL adalah sebuah perangkat lunak sistem manajemen basis data SQL (bahasa Inggris: database management system) atau DBMS yang multithread, multi-user, dengan sekitar 6 juta instalasi di seluruh dunia. MySQL AB membuat MySQL tersedia sebagai perangkat lunak gratis di bawah lisensi GNU General Public License (GPL), tetapi mereka juga menjual dibawah lisensi komersial untuk kasus-kasus dimana penggunaannya tidak cocok dengan penggunaan GPL (Solichin, 2009).

\section{METODOLOGI}

\subsection{Identifikasi Masalah Dan Sumber \\ Masalah}

Masalah yang terjadi dalam proses pemberian kredit adalah pihak koperasi dalam menentukan pemohon cenderung memilih secara subyektif sehingga keputusan yang diambil kurang berkualitas dan tingkat kemampuan menganalisa masih rendah, sehingga rentan terhadap kesalahan dalam proses analisa pemberian kredit.

\subsection{Metode Pengumpulan Data}

a. Wawancara

Wawancara dilakukan dengan cara tanya jawab secara langsung dengan pengurus serta karyawan Koperasi Roda Sejahtera Semarang.

b. Observasi

Dalam metode observasi, penulis melakukan pengambilan data dengan cara melakukan pengamatan secara langsung proses pengajuan kredit di Koperasi Roda Sejahtera Semarang, selain itu penulis juga melakukan pengamatan langsung dari sumber-sumber penelitian.

c. Studi literature

Merupakan suatu studi dengan teknik pengumpulan data dimana penulis mempelajari, literatur yang ada untuk mendukung landasan teoritis penulisan serta pengumpulan data dari instansi yang berkaitan dengan masalah yang akan di bahas sebagai pendukung penelitian. 


\subsection{Metode Pengembangan Sistem}

Metode pengembangan sistem yang akan digunakan adalah model sekuensial linier (clasic life cycle / waterfall model) sering disebut Model Waterfall. Dalam metode tersebut, terdapat beberapa tahapan, yaitu:

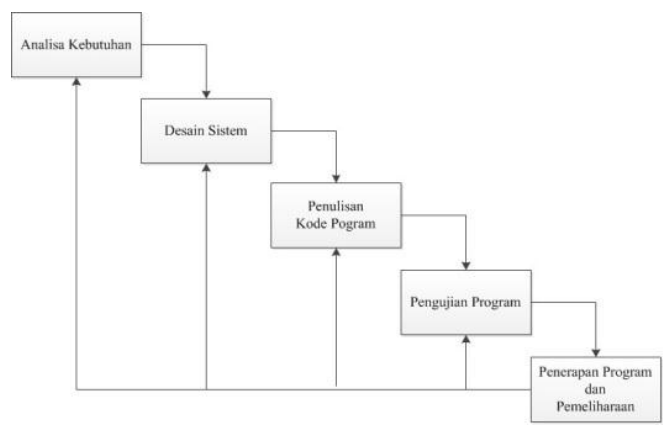

Gambar 3.1 Metode Pengembangan Sistem Waterterfall

a. Analisis Kebutuhan Sistem Informasi

b. Perancangan (Design)

c. Pengkodean (Coding)

d. Pengujian (Testing)

e. Perawatan (Maintenance)

\subsection{Analisa SPK Penilaian Kelayakan} Kredit Menggunakan Metode SAW

Penentuan penilaian kelayakan kredit di Koperasi Roda Sejahtera Semarang menggunakan kriteria penentuan dengan factor 5 C yaitu: Character (kepribadian), Capital (uang muka), Capacity (kemampuan), Collateral (jaminan), dan Condition (kondisi).

a. Pemberian Bobot Perkriteria

Langkah awal metode Simple Additive Weighting adalah pemberian nilai bobot di setiap kriteria pemohon kredit. Kelima kriteria tersebut dapat dibuat tabel sebagai berikut:

Tabel 3.1 Pemberian Bobot Kriteria

\begin{tabular}{|c|c|c|}
\hline & Neraca Kriteria & Nilai Bobot \\
\hline C1 & Character (kepribadian) & 25 \\
\hline C2 & Capital (uang muka) & 10 \\
\hline C3 & Capacity (kemampuan) & 45 \\
\hline C4 & Collateral (jaminan) & 10 \\
\hline C5 & Condition (kondisi) & 10 \\
\hline
\end{tabular}

b. Pemberian Nilai Skor pada Tiap Kriteria Langkah selanjutnya dibuat suatu tingkatan kiteria berdasarkan alternatif (pemohon kredit) yang telah ditentukan kedalam nilai skor. Rating kecocokan setiap alternatif pada setiap kriteria seperti tabel berikut:
Tabel 3.2 Nilai Skor Kriteria Character

\begin{tabular}{|c|l|c|}
\hline No. & \multicolumn{1}{|c|}{ Jumlah Anggota Keluarga } & Skor \\
\hline 1 & 0 sampai dengan 1 orang & 100 \\
\hline 2 & 2 sampai dengan 3 orang & 80 \\
\hline 3 & 4 sampai dengan 5 orang & 40 \\
\hline 4 & 6 sampai dengan 7 orang & 30 \\
\hline 5 & Lebih dari 8 orang & 20 \\
\hline
\end{tabular}

Tabel 3.3 Nilai Skor Kriteria Capital

\begin{tabular}{|c|l|c|}
\hline No. & Pendapatan Nasabah dalam Satu Bulan & Skor \\
\hline 1 & Lebih dari Rp. 5.000 .000 & 100 \\
\hline 2 & Rp. $4.000 .000-$ Rp. 5.000 .000 & 80 \\
\hline 3 & Rp. $3.000 .000-$ Rp. 3.999 .0999 & 60 \\
\hline 4 & Rp. $1.000 .000-$ Rp. 2.999 .999 & 40 \\
\hline 5 & Kurang dari Rp.1.000.000 & 20 \\
\hline
\end{tabular}

Tabel 3.4 Nilai Skor Kriteria Capacity

\begin{tabular}{|c|l|c|}
\hline No. & \multicolumn{1}{|c|}{ Pendapatan Nasabah dalam Satu Bulan } & Skor \\
\hline 1 & PNS Gologan IV & 100 \\
\hline 2 & Pegawai Swasta Masa Kerja lebih dari 15 tahun & 100 \\
\hline 3 & Perwira TNI/POLRI & 100 \\
\hline 4 & PNS Golongan III & 80 \\
\hline 5 & Pegawai Swasta Masa Kerja lebih dari 10-15 tahun & 80 \\
\hline 6 & Wiraswasta & 80 \\
\hline 7 & PNS Golongan III & 60 \\
\hline 8 & Pegawai Swasta Masa Kerja dari 5-10 tahun & 60 \\
\hline 9 & Pensiunan PNS Golongan IV & 60 \\
\hline 10 & Pensiunan Perwira TNI/POLRI & 60 \\
\hline 11 & PNS Golongan I & 50 \\
\hline 12 & Pegawai Swasta Masa Kerja kurang dari 5 tahun & 50 \\
\hline 13 & Bintara TNIPolri & 50 \\
\hline 14 & Pensiunan PNS Golongan IIII & 50 \\
\hline 15 & Prajurit TNIPOLRI & 30 \\
\hline 16 & Pensiuanan PNS Golongan II & 30 \\
\hline 17 & Pensiuanan Bintara TNI/PORI & 30 \\
\hline 18 & Pensiunan PNS Golongan I & 30 \\
\hline 19 & Pensiunan Prajurit TNI/POLRI & \\
\hline 20 & Lainnya & 30 \\
\hline
\end{tabular}

Tabel 3.5 Nilai Skor Kriteria Collateral

\begin{tabular}{|c|l|c|}
\hline No. & \multicolumn{1}{|c|}{ Jaminan BPKB } & Skor \\
\hline 1 & BPKB Sepeda Motor tahun 2014 & 100 \\
\hline 2 & BPKB Sepeda Motor tahun 2013 & 80 \\
\hline 3 & BPKB Sepeda Motor tahun 2012 & 50 \\
\hline 4 & BPKB Sepeda Motor tahun 2011 & 30 \\
\hline 5 & BPKB Sepeda Motor tahun 2010 & 20 \\
\hline
\end{tabular}


Tabel 3.6 Nilai Skor Kriteria Condition

\begin{tabular}{|c|l|c|}
\hline No. & Pendapatan Nasabah dalam Satu Bulan & Skor \\
\hline 1 & Saldo Lebih dari Rp. 20.000 .000 & 100 \\
\hline 2 & Saldo Rp. 10.000 .000 - Rp. 20.000 .000 & 80 \\
\hline 3 & Saldo Rp. 5.000.000 - Rp. 9.999.999 & 60 \\
\hline 4 & Saldo Rp. 1.000 .000 - Rp. 4.999 .999 & 40 \\
\hline 5 & Saldo Kurang dari Rp.1.000.000 & 20 \\
\hline
\end{tabular}

c. Penjabaran Alternatif Pada Setiap Kriteria Langkah selanjutnya penjabaran alternatif setiap kriteria yang telah dikonversikan dengan nilai Skor. Berikut perhitungan berdasarkan contoh kasus. Diambil sample pemohon kredit dengan nama "Budi", dengan data sebagai berikut:

Tabel 3.7 Tabel Sampel Kriteria Pemohon

\begin{tabular}{|c|c|c|c|}
\hline \multirow{2}{*}{ Kriteria } & \multicolumn{3}{|c|}{ Alternatif } \\
\cline { 2 - 4 } & Kriteria Macet & Budi & Kriteria Lancar \\
\hline C1 & $\begin{array}{c}\text { sampai dengan 7 } \\
\text { orang }\end{array}$ & $\begin{array}{c}\text { 2 sampai dengan 3 } \\
\text { orang }\end{array}$ & $\begin{array}{c}\text { 0 sampai dengan 1 } \\
\text { orang }\end{array}$ \\
\hline C2 & Kurang dari & Rp. 1.000.000-Rp. & Lebih dari Rp. \\
& Rp.1.000.000 & 2.999 .999 & 5.000 .000 \\
\hline C3 & Pensiunan PNS & Pegawai Swasta & Perwira TNI/POLRI \\
& Golongan IV & Masa Kerja dari 5-10 & \\
\hline C4 & BPKB Sepeda & BPKB Sepeda Motor & BPKB Sepeda Motor \\
& Motor tahun 2012 & tahun 2012 & tahun 2014 \\
\hline C5 & Saldo Rp. 5.000.000 & Saldo Lebih dari Rp. & Saldo Lebih dari Rp. \\
& - Rp. 9.999.999 & 20.000 .000 & 20.000 .000 \\
\hline
\end{tabular}

Keterangan:

$\mathrm{C} 1=$ Character

$\mathrm{C} 2=$ Capital

$\mathrm{C} 3$ = Capacity

$\mathrm{C} 4=$ Collateral

$\mathrm{C} 5=$ Condition

Diambil 2 kriteria, yaitu kriteria kredit macet dan kriteria kredit lancar. Dua titik tersebut digunakan untuk perbandingan skor "Budi".

Berdasarkan data di atas, dibentuk matriks keputusan dengan label $[\mathrm{X}]$ yang dikonversikan dengan nilai Skor, seperti tabel berikut.

Tabel 3.8 Tabel Rating Kecocokan Alternatif pada Setiap Kriteria

\begin{tabular}{|c|c|c|c|c|c|}
\hline \multirow{2}{*}{ Kriteria } & \multicolumn{5}{|c|}{ Alternatif } \\
\cline { 2 - 6 } & $\mathrm{C} 1$ & $\mathrm{C} 2$ & $\mathrm{C} 3$ & $\mathrm{C} 4$ & $\mathrm{C} 5$ \\
\hline Macet & 30 & 20 & 60 & 50 & 60 \\
\hline Budi & 80 & 40 & 60 & 50 & 100 \\
\hline Lancar & 100 & 100 & 100 & 100 & 100 \\
\hline
\end{tabular}

Bobot kriteria sama dengan di atas, yaitu: $\mathrm{C} 1=25 \%$; $\mathrm{C} 2=10 \% ; \mathrm{C} 3=45 \% ; \mathrm{C} 4=10 \%$; dan
C5 $=10 \%$, maka penyelesaiannya adalah sebagai berikut:

Vektor bobot $[\mathrm{W}]=\{25,10,45,10,10\}$ membuat matriks keputusan $\mathrm{X}$, dibuat dari tabel kecocokan sebagai berikut:

$$
\mathrm{X}=\left[\begin{array}{ccccc}
30 & 20 & 60 & 50 & 60 \\
80 & 40 & 60 & 50 & 100 \\
100 & 100 & 100 & 100 & 100
\end{array}\right]
$$

Melakukan normalisasi matriks dengan cara menghitung nilai rating kinerja ternormalisasi (rij).

$$
R_{i j}=\frac{C_{i j}}{\operatorname{Max} C_{i j}}
$$

Perhitungan:

$$
\begin{aligned}
& R 11=\frac{30}{\max (20,80,100)}=\frac{30}{100}=0,3 \\
& R 12=\frac{20}{\max (20,80,100)}=\frac{20}{100}=0,2 \\
& R 13=\frac{60}{\max (30,60,100)}=\frac{60}{100}=0,6 \\
& R 14=\frac{50}{\max (20,80,100)}=\frac{50}{100}=0,5 \\
& R 15=\frac{60}{\max (20,80,100)}=\frac{60}{100}=0,6 \\
& R 21=\frac{80}{\max (20,80,100)}=\frac{80}{100}=0,8 \\
& R 22=\frac{40}{\max (20,80,100)}=\frac{40}{100}=0,4 \\
& R 23=\frac{60}{\max (30,60,100)}=\frac{60}{100}=0,6
\end{aligned}
$$




$$
\begin{aligned}
& R 24=\frac{50}{\max (20,80,100)}=\frac{50}{100}=0,5 \\
& R 25=\frac{100}{\max (20,80,100)}=\frac{100}{100}=1 \\
& R 31=\frac{100}{\max (20,80,100)}=\frac{100}{100}=1 \\
& R 32=\frac{100}{\max (20,80,100)}=\frac{100}{100}=1 \\
& R 33=\frac{100}{\max (30,60,100)}=\frac{100}{100}=1 \\
& R 34=\frac{100}{\max (20,80,100)}=\frac{100}{100}=1 \\
& R 35=\frac{100}{\max (20,80,100)}=\frac{100}{100}=1
\end{aligned}
$$

Melakukan proses penilaian dengan cara mengalikan matriks ternormalisasi $(\mathrm{R})$ dengan nilai bobot $(\mathrm{W})$.

$$
\mathrm{W} . \mathrm{X}=\left[\begin{array}{lllll}
25 & 10 & 45 & 10 & 10
\end{array}\right] \cdot\left[\begin{array}{ccccl}
0,3 & 0,2 & 0,6 & 0,5 & 0,6 \\
0,8 & 0,4 & 0,6 & 0,5 & 1 \\
1 & 1 & 1 & 1 & 1
\end{array}\right]
$$

Terakhir menentukan nilai preverensi untuk setiap alternatif (Vi) dengan cara menjumlahkan hasil kali antara matriks ternormalisasi (R) dengan nilai bobot (W). Penjumlahan hasil kali matriks ternomalisasi menghasilkan angka sebagai berikut:

$$
\begin{gathered}
\mathrm{VI}=(25)(0,3)+(10)(0,2)+(45)(0,6)+(10)(0,5)+(10)(0,6)=47,5 \\
\mathrm{VI}=(25)(0,8)+(10)(0,4)+(45)(0,6)+(10)(0,5)+(10)(1)=66 \\
\mathrm{VI}=(25)(1)+(10)(1)+(45)(1)+(10)(1)+(10)(1)=100
\end{gathered}
$$

Dari perhitungan tersebut diambil kesimpulan bahwa nilai V1 dan V3 adalah nilai statis yang berubah hanya jika bobot kriteria diubah, sedangkan nilai V2 adalah nilai pemohon kredit. Nilai V1 merupakan nilai minimum dimana kredit macet mungkin terjadi dan V3 merupakan nilai maksimum dimana kredit berjalan lancar, sedangkan nilai V2 merupakan nilai "Budi". Oleh karena itu, nilai kelayakan kredit berada diatas angka V1 dan dibawah / sama dengan V3. Dalam kasus ini, nilai kelayakannya adalah $60-100$, jadi Budi dinyatakan layak menerima kredit dengan nilai 66.

\section{HASIL DAN PEMBAHASAN}

\subsection{Desain Sistem}

a. Flowchart Sistem Pendukung Keputusan Penilaian Kredit

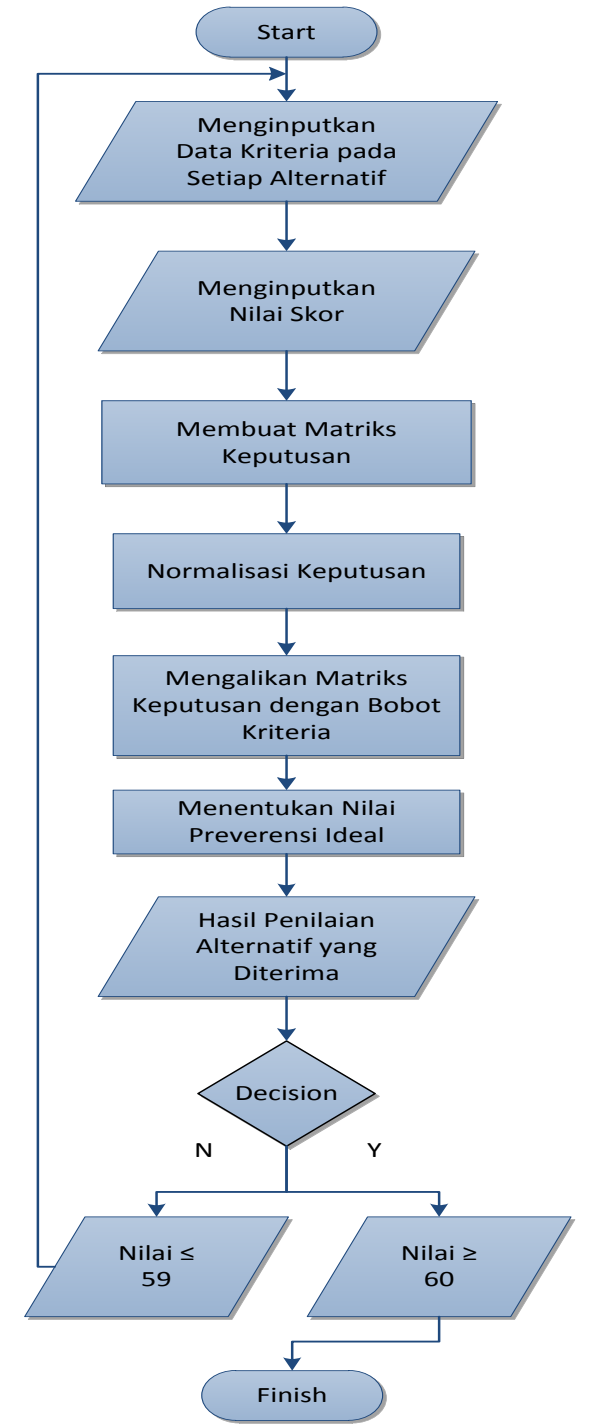

Gambar 4.1 Flowchart Sistem Pendukung Keputusan

b. Use Case Diagram

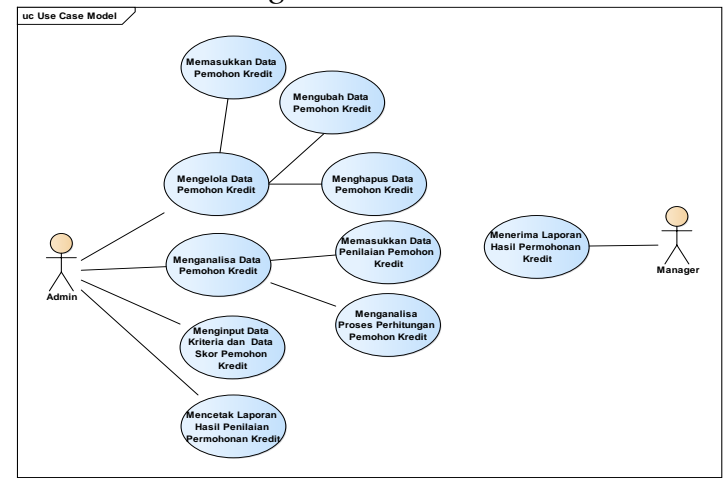

Gambar 4.2 Use Case Diagram

c. Class Diagram 


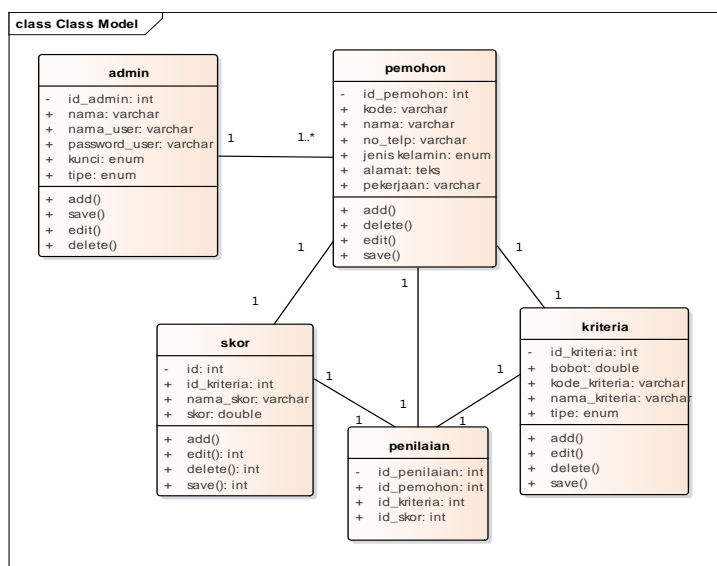

Gambar 4.3 Class Diagram

\section{HASIL DAN PEMBAHASAN}

a. Halaman Utama

Halaman utama adalah halaman yang pertama muncul setelah melakukan proses login sistem. Terdapat beberapa menu dalam halaman ini diantaranya adalah menu utama, menu analisa dan menu laporan.

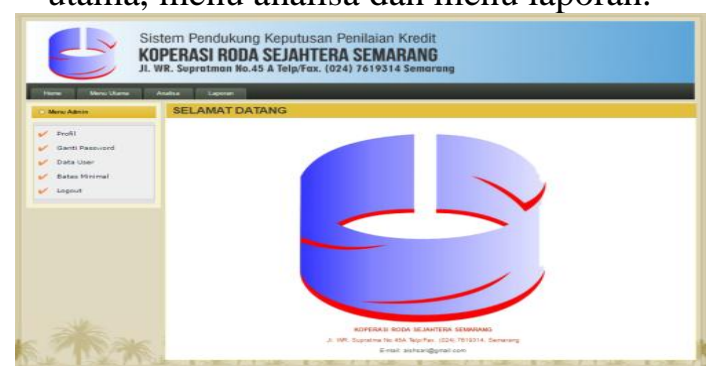

Gambar 5.1 Halaman Utama

b. Halaman Data Pemohon

Halaman data pemohon adalah halaman yang digunakan untuk menginputkan data pemohon kredit. Setelah diinputkan maka sistem akan menampilkan data pemohon yang sudah di inputkan, yaitu informasi pemohon kredit yang terdiri dari nama, alamat, nomer telepon, alamat, dan pekerjaan pemohon

kredit.

\begin{tabular}{|c|c|c|c|c|}
\hline \multicolumn{5}{|l|}{ DATA PEMOHON } \\
\hline \multicolumn{4}{|l|}{ DATA PEMOHON } & \multirow[t]{2}{*}{ Thath } \\
\hline No Kode Nama & Manat & TEepon & LP Pelejian & \\
\hline 1 P01 Ana & IN Kipang Sendang mulyo Semarang & 0058765573644 & $P$ Pensinanan PNS & Exithipos \\
\hline $2 \quad \mathrm{P02} \quad$ Budi & dlB Beruang Raya Gajansari Semarang & 0877993783823 & L Peganai Swasta & Estitiapu \\
\hline 3 P03 Ahmad & Jn Firastya 2 Pedurungagn Semarang & 009698726323 & $1 \mathrm{TN}$ & Esithipou \\
\hline $\begin{array}{lll}4 & \text { P04 Sann Afijani }\end{array}$ & In Pedurungan Lor Semarang & 081982734234 & $P$ FNS & Estrithape \\
\hline $5 \quad$ P05 Santo & In Manglang KW 20 Semararang & 062283748845 & L Kontrakhor & Easthiapu \\
\hline
\end{tabular}

Gambar 5.2 Halaman Data Pemohon

c. Halaman Data Kriteria

Halaman data kriteria adalah halaman yang digunakan untuk menampilkan semua data kriteria pemohon kredit yang telah diinput oleh user. Terdapat juga menu pengolahan data seperi tambah, edit dan hapus pada setiap datanya.

\begin{tabular}{|c|c|c|c|c|c|}
\hline \multicolumn{6}{|c|}{ DATA KRITERIA } \\
\hline & \multicolumn{4}{|c|}{ 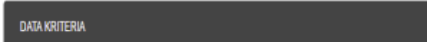 } & \multirow[t]{2}{*}{ Inth } \\
\hline No & kostevithe & Nena Kitira & Tree & Bsode & \\
\hline 1 & 001 & Keptotatian & Benert & 25 & Earthoun \\
\hline 2 & 002 & Uang wita & Benent & 10 & Earthour \\
\hline 3 & Cos & Kemanp.an & Beneth & 45 & Eathiaper \\
\hline 4 & $\mathrm{COS}$ & sarizan & Bnentr & 10 & Earthow \\
\hline 5 & 005 & Konsasi & Benert & 10 & Eathito \\
\hline
\end{tabular}

Gambar 5.3 Halaman Data Kriteria

d. Halaman Data Skor

Halaman data skor berisikan skor dari masing-masih kriteria yang telah diinputkan oleh user. Halaman ini akan menampilkan nilai skor tertinggi yaitu 100 dan nilai skor terendah yaitu 30 .

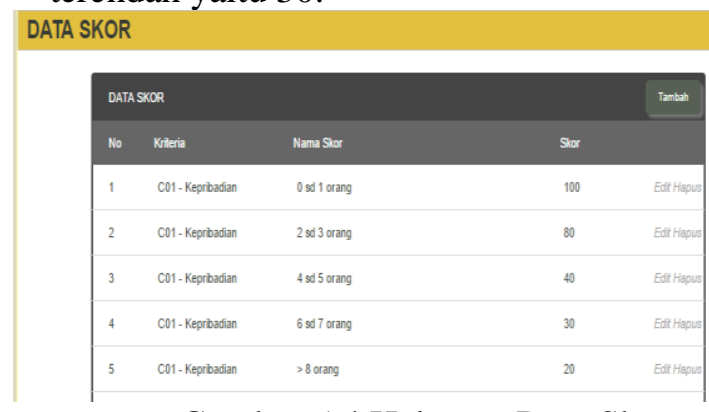

Gambar 5.4 Halaman Data Skor

e. Halaman Penilaian

Halaman penilaian adalah halaman dimana admin dapat menginputkan masing-masing kriteria dari setiap pemohon kredit mulai dari kepribadian, uang muka, kemampuan, jaminan dan kondisi sesuai data yang telah diperoleh.

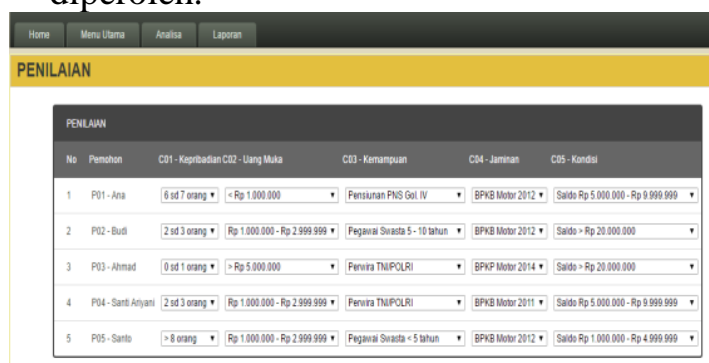

Gambar 5.5 Halaman Penilaian

f. Halaman Hasil Analisa

Halaman hasil analisa berisikan data dari proses penilaian data pemohon kredit yang telah diinput oleh admin, dalam halaman ini akan di tampilkan hasil dari proses analisa 
penilaian kelayakan kredit menggunakan metode Simple Additive Weighting yaitu proses penilaian, normalisasi, nilai akhir dan hasil analisa.

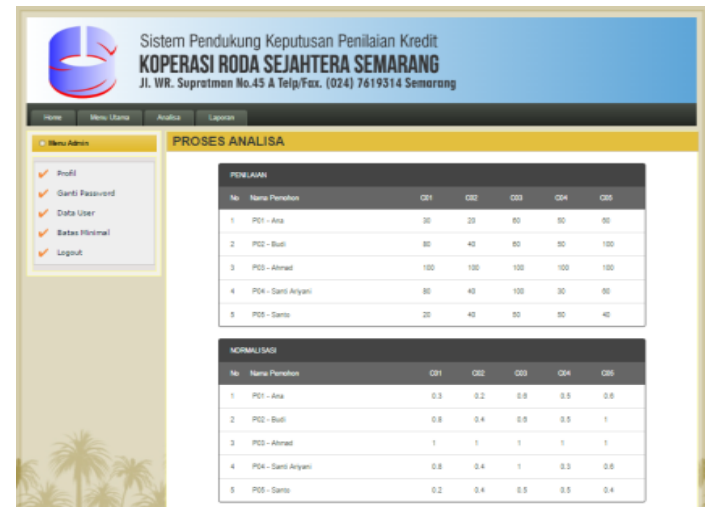

Gambar 5.6 Halaman Hasil Analisa

g. Halaman Laporan Permohonan Kredit

Halaman laporan pemohon kredit adalah halaman yang berfunsi untuk menampilkan hasil analisa dengan menggunakan metode Simple Additive Weighting yang akan memberikan penilaian diterima / ditolaknya pengajuan kredit sebagi bahan pertimbangan menentukan keputusan pemberian kredit nasabah, dalam laporan ini juga berisi lengkap data mengenai nasabah beserta nilai dari masing-masing kriteria.

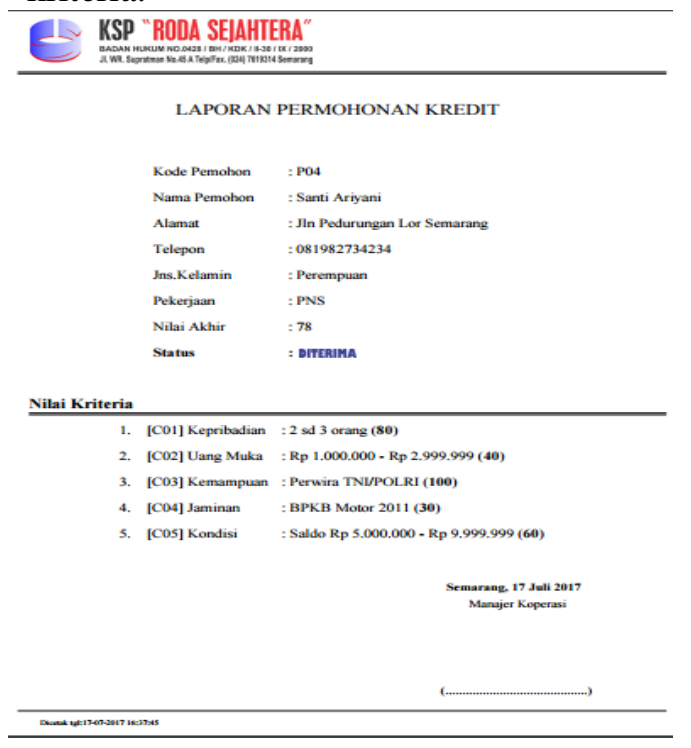

Gambar 5.7 Halaman Laporan Permohonan Kredit

\section{KESIMPULAN DAN SARAN}

Sistem pendukung keputusan penilaian kelayakan kredit pada Koperasi Roda Sejahtera dengan menggunakan Metode Simple Additive
Weighting sehingga dapat memberikan informasi kepada manajer dengan hasil perhitungan kriteria yang diperoleh.

Penelitian ini dapat dikembangkan dengan menambahkan menu yang mencakup seluruh prosedur perkreditan yang ada seperti kapasitas melunasi kredit, penagihan kredit dan lain-lain, sehingga program dapat dipergunakan secara optimal.

\section{DAFTAR PUSTAKA}

Arfiyanti, I., \& Purwanto, E., 2012, Aplikasi Sistem Pendukung Keputusan Pemberian Kelayakan Kredit Pinjaman pada Bank Rakyat Indonesia Unit Segiri Samarinda dengan Metode Fuzzy MADM (Multiple Attribute Decision Making) menggunakan SAW (Simple Additive Weighting), Semantik 2012, Semarang, Hal. 120.

Dewi, M., 2011, Pembuatan Situs Web Almamater Perguruan Tinggi Menggunakan PHP dan MySql, Makalah Tugas Akhir, Universitas Diponegoro, Hal. 2.

Kusumadewi Sri, Hartati Sri, Harjoko Agus, Wardoyo Retantyo, 2006, Fuzzy MultiAttribute Decision Making, Graha Ilmu, Yogyakarta.

Listiyono, H., Sunardi, dan Khristianto, T., 2011, Rekayasa Perangkat Lunak Sistem Pendukung Keputusan Pembicaraan Kredit (Studi Kasus: BPR Argo Dana Semarang). Jurnal Teknologi Informasi DINAMIK Volume 16 No.1 Semarang, Hal. 72-76.

Solichin, A., 2009, Pemrograman Web dengan PHP dan MySql, Universitas Budi Luhur, Jakarta

Warman, I., Usman, 2015, Aplikasi Perkreditan Berbasis Web pada PT. Prioritas Cabang Kabupatrn Pasaman Barat, Jurnal Teknoif Volume 3 No. 1 , Hal. 40. 